\title{
Kombinasi Model Pembelajaran NHT dan Snowball Throwing Untuk Mengembangkan Ketrampilan Abad 21 Mahasiswa Universitas Muhammadiyah Sorong
}

\author{
${ }^{1}$ Arie Anang Setyo, ${ }^{2}$ Mulyono \\ ${ }^{1}$ Universitas Muhammadiyah Sorong, ${ }^{2}$ STAIN Sorong \\ ${ }^{\text {arieanangsetyo.ums@gmail.com, }}, \underline{\text { mulyonosmk@gmail.com }}$
}

\begin{abstract}
Abstrak
Penetian ini bertujuan untuk mengatasi rendahnya ketrampilan abad 21 mahasiswa program studi pendidikan matematika fakultas keguruan dan ilmu pendidikan Universitas Muhammadiyah Sorong, melalui kombinasi model pembelajaran kooperatif tipe NHT dan Snowball Throwing ( NHT\&ST), desain penelitian menggunakan "One Group Pretest- postest Design". Intrumen penelitian yang digunakan adalah lembar pengamatan pembelajaran, tes hasil belajar dan angket respons mahasiswa. Data hasil penelitian dianalisis dengan analisis statistik deskriptif dan infrensial. Hasil pengamatan Keterlaksanaan pembelajaran dan aktivitas mahasiswa berada pada rata-rata 3,85 (77\%) kategori Sangat baik, dan 3,86 (77\%) dengan kategori Baik, data hasil respons mahasiswa dengan rata-rata 4,13 $(82 \%)$ berada pada kategori sangat setuju (SS). Hasil analisis infrensial dengan uji z satu pihak dengan uji pihak kiri menghasilkan nilai $\mathrm{Z}$ hitung $(3,6215)>\mathrm{Z}$ tabel $(-1654)$, hasil anailis statistik infrensial disimpulkan bahwa pada signifikansi 5\%, ketrampilan Abad 21 Mahasiswa Universitas Muhammadiyah Sorong dengan menerapkan Kombinasi Model Pembelajaran Kooperatif Tipe NHT Dan Snowball Throwing (NHT\&ST) tidak kurang dari $60 \%$ dari kriteria ideal yang ditetapkan yaitu $60 \%$. Berdasarkan hasil statistik deskriptif dan infrensial disimpulkan bahwa Pelaksanaan pembelajaran kombinasi model pembelajaran kooperatif tipe NHT dan Snowball Throwing (NHT\&ST) mampu mengembangkan ketrampilan abad 21 mahasiswa Semester IV Program studi Pendidikan Matematika Fakultas Keguruan dan Ilmu Pendidikan Universitas Muhammadiyah Sorong tahun akademik 2018/2019.
\end{abstract}

Kata kunci: Model Pembelajaran, Kombinasi NHT\&ST, Ketrampilan Abad 21,

\begin{abstract}
The aim of this research is to overcome the low skill of the 21 st century students of the mathematics education study program in the faculty of teaching and education at the Universitas Muhammadiyah Sorong, through a combination of NHT and Snowball Throwing (NHT \& ST) cooperative learning models, research design using "One Group Pretest-posttest Design". The research instruments used were learning sheets, student achievement tests and student response questionnaires. The research data were analyzed with descriptive and infra-statistics analysis. Student Evaluation and Evaluation Results with an average of 3.85 (77\%) Very good category, and $3.86(77 \%)$ with Good category, student response data with an average of 4.13 (82\%) Remain in the category strongly agree (SS). The results of the analysis of information by one-tailed test with the left hand side result in arithmetic values (3.6215)> Z tables (-1654), statistically significant results of 5\% results, 21st Century skills of Muhammadiyah University Students, Cooperative Learning Models, NHT and Snowball Types Throwing (NHT \& ST) is not less than 60\% of the
\end{abstract}


ideal criteria set which is $60 \%$. Based on the results of descriptive and infrational research, it was concluded that the implementation of the learning combination of the NHT and Snowball Throwing (NHT \& ST) cooperative learning models was able to develop 21st century skills of the 4th semester students of the Mathematics Education Study Program, Faculty of Teacher Training and Education, Universitas Muhammadiyah Sorong, academic year 2018/2019

Keywords: Learning Model, Combination of NHT\&ST, $21^{\text {st }}$ Century Skills

\section{PENDAHULUAN}

Pelaksanaan pembelajaran atau yang lebih dikenal dengan proses pembelajaran selalu mengalami perbaikan dan penyempurnaan. Proses pembelajaran yang dahulu lebih menekankan pada pembelajaran yang lebih mengutamakan pada peran pendidik atau guru, yaitu guru memberikan materi kepada siswa sedangkan siswa hanya mendengarkan atau mencatat apa yang disampaikan guru (Trisnawati, 2019), kini lebih ditekankan pada suatu proses pembelajaran yang menekankan aktivitas peserta didik atau yang lebih dikenal dengan pembelajaran yang berpusat pada peserta didik. Pembelajaran yang berpusat pada peserta didik diharapkan dapat menyelesaikan permasalahan yang selalu dirasa peserta didik, dimana matematika masih dianggap sebagai pembelajaran yang tidak menyenangkan bahkan membosankan, terlebih lagi jika di ajarkan pada jam-jam terakhir (Setyo, 2018).

Proses pembelajaran di perguruan tinggi juga senantiasa mengalami perbaikan dan penyempurnaan melalui kegiatan-kegiatan yang berpengaruh dalam peningkatkan kualitas proses pembelajaran, salah satunya melalui kegiatan penelitian dan perbaikan proses pembelajaran. Proses pembelajaran pada jenjang pendidikan tinggi terlebih lagi kepada para calon pendidik hendaknya dirancang untuk mengembangkan ketrampilan yang dibutuhkan mahasiswa untuk bersaing dan berkompetisi baik pada dunia pendidikan sebagai seorang pendidik, atau bahkan pada pekerjaan lain yang relevan. Keterampilan-keterampilan yang diharapkan diperoleh mahasiswa pada saat proses pembelajaran selaras dengan ketrampilan abad 21 adalah kemampuan Berfikir Kreatif (Creatif Thinking), Berfikir Kritis dan Pemecahan Masalah (Critical Thinking and Proplem Solving), Berkomunikasi (Communication) dan Berkolaborasi (Collaboration) (Arifin, 2017). 
Selaras dengan hasil penelitian di atas, peneliti mencoba mengkaji dan mengkombinasikan kelebihan-kelebihan dari kedua model pembelajaran yaitu Number Head Together dan Snowball Throwing yang kemudian di singkat dengan model pembelajaran tipe NHT \& ST untuk mengembangkan keterampilan abad 21 mahasiswa program studi pendidikan matematika universitas muhammadiyah sorong, mata kuliah geometri analitik materi persamaan lingkaran dan parabola. Rumusan masalah dalam penelitian ini adalah apakah Kombinasi Model Pembelajaran NHT dan Snowball Throwing dapat mengembangkan ketrampilan Abad 21 mahasiswa UM- Sorong.

\section{METODE PENELITIAN}

Desain penelitian yang digunakan dalam penelitian ini adalah “One Group Pretest- postest Design" yang merupakan salah satu bentuk desain dari pre-eksperimental. Model desain tersebut adalah sebagai berikut:

\begin{tabular}{|l|l|l|}
\hline $\mathbf{X}$ & $\mathbf{O}$ & $\mathbf{X}$ \\
\hline
\end{tabular}

Sumber: (Lestari, 2015)

Keterangan:

$\mathrm{O}=$ Perlakuan/treatment dengan Kombinasi Model Pembelajaran NHT dan Snowball Throwing Untuk Mengembangkan Ketrampilan Abad 21 Mahasiswa Universitas Muhammadiyah Sorong $\mathrm{X}=$ pretest/Posttest variable yang diamati

\section{Lokasi dan Subjek Penelitian}

Penelitian ini dilaksanakan pada Mahasiswa Program studi Pendidikan matematika Universitas Muhammadiyah Sorong semester 4 mata kuliah geometri analitik, dengan subjek penelitian berjumlah 37 orang, terdiri dari 7 orang laki-laki dan 30 orang perempuan.

\section{Instrumen Penelitian dan analisis data}

Instrumen penelitian yang digunakan dalam penelitian ini adalah Lembar pengamatan pembelajaran, Tes hasil belajar (Pretest \& posttest) serta angket respons mahasiswa. Teknik analisis data yang digunakan dalam penelitian ini adalah analisis statistik deskriptif dan infrensial. 
Tabel 2.1 Kriteria Keterlaksanaan Pembelajaran

\begin{tabular}{cc}
\hline Hasil keterlaksanaan pembelajaran $(\%)$ & Kriteria \\
\hline $86-100$ & Sangat baik \\
$76-85$ & Baik \\
$60-75$ & Cukup \\
$55-59$ & Kurang \\
$\leq 54$ & Kurang sekali \\
\hline
\end{tabular}

Sumber: Purwanto (2010)

Tabel 2.2 Ktriteria Aktivitas Mahasiswa

\begin{tabular}{|c|c|c|}
\hline Aktivitas Mahasiswa (\%) & Kriteria & \\
\hline $76-100$ & Sangat baik & \\
\hline $51-75$ & Baik & \\
\hline $26-50$ & Cukup Baik & \\
\hline$\leq 25$ & Kurang Baik & \\
\hline & & Sumber: Tria \\
\hline \multicolumn{3}{|c|}{ Tabel. 2.3 Tabel Kriteria Capaian Hasil Belajar Mahasiswa } \\
\hline Rentang nilai & Predikat & \\
\hline $0-49$ & $\mathrm{E}$ & \\
\hline $50-59$ & $\mathrm{D}$ & \\
\hline $60-69$ & $\mathrm{C}$ & \\
\hline $70-79$ & $\mathrm{~B}$ & \\
\hline $80-100$ & A & \\
\hline
\end{tabular}

Sumber: Kategori Penilaian Mahasiswa dalam http://siakad.um-sorong.ac.id 
Tabel 2.4 Kriteria Penilaian jawaban pada Angket Respons

\begin{tabular}{lcc}
\hline \multicolumn{1}{c}{ Alternatif Jawaban } & \multicolumn{2}{c}{ Skor tiap jawaban } \\
& Pernvataan Positif & Pernvataan Negatif \\
\hline Sangat tidak Setuju (STS) & 1 & 5 \\
Tidak setuju (TS) & 2 & 4 \\
Netral (N) & 3 & 3 \\
Setuju (S) & 4 & 2 \\
Sangat setuju (SS) & 5 & 1 \\
\hline
\end{tabular}

Untuk menghitung data hasil respons mahasiswa digunakan rumus sebagai berikut:

$$
\mathrm{P}=\frac{n}{N} \times 100 \%
$$

$\mathrm{P}=$ Persentase Hasil penilaian respons mahasiswa, $\mathrm{n}=$ Jumlah skor yang diperleh, $\mathrm{N}=$ Jumlah skor maksimum,

Hasil penilaian kemudian dikategorikan berdasarkan kriteria pada table 2.5

Tabel 2.5 Kriteria hasil angket respons

\begin{tabular}{cc}
\hline Hasil Respons Mahasiswa (\%) & Kriteria \\
\hline $1-20$ & Sangat tidak setuju (STS) \\
$21-40$ & Tidak Setuju (TS) \\
$41-60$ & Netral (N) \\
$61-80$ & Setuju (S) \\
$81-100$ & Sangat Setuju(SS) \\
\hline
\end{tabular}

\section{Uji Statistik infrensial}

Untuk menguji hipotesis menggunakan uji statistik infrensial menggunakan uji z pihak kiri dengan rumus:

$$
\mathrm{Z}_{\text {hitung }}=\frac{\frac{x}{n}-p}{\sqrt{\frac{p(1-p)}{n}}}
$$

Keterangan: $\mathrm{x}=$ Banyak data yang termasuk kategori hipotesis nol, $\mathrm{n}=$ Banyak data, $\mathrm{p}=$ Proporsi pada hipotesis 


\section{HASIL PENELITIAN}

Tabel 3.1 Data hasil pengamatan keterlaksanaan pembelajaran

\begin{tabular}{ccccc}
\hline No & $\begin{array}{c}\text { Pengamatan } \\
\text { Keterlaksanaan }\end{array}$ & Rata-rata & $\begin{array}{c}\text { Persentase } \\
(\boldsymbol{\%})\end{array}$ & Kategori \\
& Pembelajaran & & & \\
\hline 1 & Pertemuan Pertama & 3,4 & 68 & Cukup \\
2 & Pertemuan Kedua & 4,2 & 84 & Baik \\
3 & Pertemuan Ketiga & 4,6 & 92 & Sangat Baik \\
4 & Pertemuan Keempat & 4,7 & 94 & Sangat Baik \\
5 & Rata-rata Total & 4.23 & 84,6 & Baik \\
\hline
\end{tabular}

Berdasarkan tabel 3.1 dapat dilihat terjadinya peningkatan nilai rata-rata pada setiap pertemuan, dengan rata-rata total mencapai 4,23 (84,6\%) berada pada kategori baik.

Tabel 3.2 Rekapitulasi hasil pengamatan aktivitas pembelajaran

\begin{tabular}{ccccc}
\hline No & $\begin{array}{c}\text { Pengamatan Aktivitas } \\
\text { Mahasiswa }\end{array}$ & Rata-rata & $\begin{array}{c}\text { Persentase } \\
(\%)\end{array}$ & Kategori \\
\hline 1 & Pertemuan Pertama & 2.9 & 58 & Baik \\
2 & Pertemuan Kedua & 3.8 & 76 & Sangat Baik \\
3 & Pertemuan Ketiga & 4.2 & 84 & Sangat Baik \\
4 & Pertemuan Keempat & 4.5 & 90 & Sangat Baik \\
5 & Rata-rata Total & 3.85 & 77 & Sangat Baik \\
\hline
\end{tabular}

Tabel 3.2 menunjukkan bahwa rata-rata terendah berada pada pertemuan pertama dengan nilai 2,9 (58\%) dengan kategori Baik, sedangkan rata-rata tertinggi terjadi pada pertemuan ke empat dengan nilai 4,5 (90\%) berada pada kategori Sangat Baik, rata-rata total hasil pengamatan aktivitas adalah 3,85 (77\%) berada pada kategori Sangat baik. 
Tabel. 3.3 Capaian Hasil Belajar Mahasiswa

\begin{tabular}{cccccc}
\hline \multirow{2}{*}{ Rentang nilai } & \multicolumn{2}{c}{ Pretest } & \multicolumn{2}{c}{ Postest } \\
& Predikat & Frekuensi & Persentase (\%) & Frekuensi & Persentase (\%) \\
\hline $0-49$ & E & 37 & 100 & 2 & 5 \\
$50-59$ & D & & & 2 & 5 \\
$60-69$ & C & & 5 & 14 \\
$70-79$ & B & & 19 & 51 \\
$80-100$ & A & & 9 & 24 \\
Jumlah & & 37 & 100 & 37 & 100 \\
\hline
\end{tabular}

Tabel 3.3 dapat dideskripsikan bahwa pada saat prestest, dari 37 mahasiswa yang mengikuti pretest rata-rata mahasiswa mendapatkan nilai dibawah 49 dengan kategori E, sedangkan pada hasil posttest menunjukkan bahwa terdapat $90 \%$ mahasiswa yang memperoleh nilai minimal predikat C

Tabel. 3.4 Data respons mahasiswa

\begin{tabular}{|c|c|c|c|c|c|c|c|c|}
\hline \multirow{3}{*}{$\begin{array}{c}\text { Uraian } \\
\text { Respons }\end{array}$} & \multirow{3}{*}{$\begin{array}{l}\underline{\text { Rata-rata }} \\
\operatorname{Max}=5\end{array}$} & \multirow{3}{*}{$\begin{array}{l}\text { Persentas } \\
\mathrm{e}(\%)\end{array}$} & \multirow{3}{*}{$\underline{\text { Kategori }}$} & \multicolumn{5}{|c|}{ Frekuensi hasil respons setiap aspek yang } \\
\hline & & & & \multicolumn{5}{|c|}{ direspons } \\
\hline & & & & 1 & 2 & 3 & 4 & 5 \\
\hline $\mathrm{P} 1(+)$ & 4.3 & 86 & SS & 1 & 0 & 6 & 11 & 19 \\
\hline $\mathrm{P} 2(+)$ & 4.1 & 82 & SS & 0 & 1 & 9 & 14 & 13 \\
\hline $\mathrm{P} 3(+)$ & 4.1 & 82 & SS & 0 & 2 & 6 & 15 & 14 \\
\hline $\mathrm{P} 4(+)$ & 3.9 & 78 & S & 1 & 5 & 8 & 6 & 17 \\
\hline $\mathrm{P} 5(+)$ & 3.8 & 76 & $\mathrm{~S}$ & 0 & 3 & 11 & 12 & 11 \\
\hline P6 (-) & 4.2 & 84 & STS & 19 & 11 & 4 & 3 & 0 \\
\hline P7 (-) & 4.5 & 90 & STS & 22 & 13 & 2 & 0 & 0 \\
\hline $\mathrm{P} 8(+)$ & 4.2 & 84 & SS & 0 & 0 & 6 & 17 & 14 \\
\hline Total & 4,13 & 82 & SS & & & & & \\
\hline
\end{tabular}

Berdasarkan tabel 3.4 dapat dilihat bahwa rata-rata total respons mahasiswa adalah 4,13 dengan kategori sangat setuju ( SS), sehingga dapat disimpulkan bahwa rata-rata mahasiswa 
merespons sangat setuju bahwa kombinasi model pembelajaran kooperatif NHT\&ST mampu mengembangkan ketrampilan Abad 21 Mahasiswa Universitas Muhammadiyah Sorong, mata kuliah Geometri Analitik.

Sebagai suatu syarat pengujian hipotesis maka perlu dilakukan uji normalitas data, dalam penelitian ini pengujian normalitas menggunakan bantuas SPSS 24 dengan hasil sebagai berikut:

Tabel 3.5 Hasil Uji Normalitas

\begin{tabular}{cc|c|c|c|c|c}
\hline & \multicolumn{3}{c|}{ Kolmogorov-Smirnov $^{\text {a }}$} & \multicolumn{3}{c}{ Shapiro-Wilk } \\
& Statistik & Df & Sig. & Statistik & Df & Sig. \\
\hline posttest & .121 & 37 & .190 & .947 & 37 & .077 \\
\hline
\end{tabular}

Berdasarkan tabel 3.5, dapat di lihat bahwa pada uji normalitas dengan KolmogorovSmirnov dan Shapiro-Wilk diperoleh nilai Signifikansi sebesar 0.190 dan 0,07, maka nilai signifikansi lebih dari 0,05 sehinnga data hasil postest berdisribusi normal, dan uji statistik yang infrensial yangh digunakan adalah statistik parametrik.

\section{Uji Hipotesis}

Hasil perhitungan dengan uji $\mathrm{Z}$ pihak kiri diperolh $\mathrm{Z}$ hitung $(3,6215)>$ dari $\mathrm{Z}$ tabel (-1654 ) maka $\mathrm{H}_{0}$ di terima, sehingga disimpulkan bahwa pada taraf kepercayaan 95\%, untuk $\mathrm{P}_{0} \geq$ 60\%, Ketrampilan Abad 21 Mahasiswa Universitas Muhammadiyah Sorong dengan menerapkan Kombinasi Model Pembelajaran Kooperatif Tipe NHT Dan Snowball Throwing (NHT\&ST) tidak kurang dari $60 \%$ dari kriteria ideal yang ditetapkan.

\section{PEMBAHASAN}

Hasil penelitian pada uraian menunjukkan bahwa keterlaksanaan pembelajaran mencapai nilai rata-rata 4,23 (84,6\%) dengan kategori Baik sedangkan aktivitas mahasiswa dengan nilai ratarata 3,85 (77\%) berada pada kategori sangat baik, sedangakan hasil belajar menunjukkan bahwa terdapat $90 \%$ mahasiswa yang memperoleh nilai minimal predikat C. hasil respons mahasiswa juga menunjukkan rata-rata mahasiswa sangat setuju bahwa kombinasi model pembelajaran kooperatif NHT\&ST mampu mengembangkan ketrampilan Abad 21 Mahasiswa Universitas Muhammadiyah 
Sorong, mata kuliah Geometri Analitik. Hal ini selaras dengan pendapat Huda (2018). Yang menyimpulkan bahwa, terdapat peningkatan hasil belajar yang signifikan dan model NHT lebih baik dari pada model Snowball Throwing. Nur (2017) juga menyimpulkan bahwa model pembelajaran kooperatif tipe Numbered Head Together (NHT) berpengaruh secara signifikan terhadap hasil belajar matematika siswa. Mulyono (2019) dalam penelitiannya menambahkan bahwa model pembelajaran koopertif tipe NHT lebih efektif diterapakan pada mahasiswa semester IV Universitas Muhammadiyah Sorong. Putra (2013) menambahkan bahwa kelas yang menggunakan Model Pembelajaran Kooperatif Tipe Numbered Head Together (NHT) mempunyai nilai hasil belajar yang lebih baik dari pada kelas yang menggunakan Model Pembelajaran Kooperatif Tipe Student Teams Achievement Division (STAD). Santiana (2014) model pembelajaran kooperatif tipe NHT berpengaruh positif terhadap hasil belajar matematika siswa dibandingkan dengan model pembelajaran konvensional

\section{KESIMPULAN}

Pelaksanaan pembelajaran kombinasi model pembelajaran kooperatif tipe NHT dan Snowball Throwing (NHT\&ST) mampu mengembangkan ketrampilan abad 21 mahasiswa Semester IV Program studi Pendidikan Matematika Fakultas Keguruan dan Ilmu Pendidikan Universitas Muhammadiyah Sorong. Secara deskriptif, hasil belajar mahasiswa menunjukkan bahwa terjadi peningkatan kemampuan abad 21 mahasiswa dalam menyelesaikan permasalaan pada tes hasil belajar yang menunjukkan bahwa dari 37 responsden 100\% berada pada rentang 0-49 dengan predikat E pada saat pretest, sedangkan hasil posttest $90 \%$ mahasiswa berada pada minimal predikat C. Hasil analisis deskriptif terhadap data Keterlaksanaan pembelajaran, aktivitas dan respons mahasiswa menunjukkan bahwa nilai rata-rata hasil pengamatan keterlaksanaan adalah 3,85 (77\%) berada pada kategori Sangat baik, sedangkan aktivitas mahasiswa berada pada kategori baik dengan rata-rata total 3,86 (77\%), hasil respons mahasiswa juga menunjukkan bahwa rata-rata hasil respons mencapai 4,13 (82\%) berada pada kategori sangat setuju (SS). Hasil analisis infrensial menggunakan uji z satu pihak dalam hal ini memakai uji pihak kiri menunjukkan bahwa nilai $\mathrm{Z}$ hitung $>\mathrm{Z}$ tabel maka $\mathrm{H}_{0}$ di terima, sehingga dapat hasil analisis statistik infrensial disimpulkan bahwa pada Ketrampilan Abad 21 Mahasiswa Universitas Muhammadiyah Sorong dengan 
menerapkan Kombinasi Model Pembelajaran Kooperatif Tipe NHT Dan Snowball Throwing

(NHT\&ST) tidak kurang dari 60\% dari kriteria ideal yang ditetapkan.

\section{DAFTAR PUSTAKA}

Arifin, Z. 2017. Mengembangkan Instrumen Pengukur Critical Thinking Skills Siswa pada Pembelajaran Matematika Abad 21. Jurnal THEOREMS (The Original Research of Mathematics), 1(2).

Lestari, K. E., \& Yudhanegara, M. R. 2015. Penelitan Pendidikan Matematika, Bandung. Refika Aditama.

Nur, M. I., \& Salam, M. 2017. Pengaruh Penerapan Model Pembelajaran Kooperatif Tipe Numbered Heads Together (Nht) Terhadap Hasil Belajar Matematika Siswa Kelas Vii Smp Negeri 1 Tongkuno. Jurnal Penelitian Pendidikan Matematika, 4(1), 99-112.

Purwanto, N. 2010. Psikologi Pendidikan: Bandung: PT Remaja Rosdakarya. Oemar Hamalik.

Putra, D. P. P., \& Rakhmawati, L. 2013. Perbandingan Model Pembelajaran Kooperatif Tipe Numbered Head Together (Nht) Dengan Model Pembelajaran Kooperatif Tipe Student Teams Achievement Division (Stad) Terhadap Hasil Belajar Siswa PADA PROGRAM DIKLAT DASAR-DASAR TEKNIK DIGITAL DI SMKN 7 SURABAYA. Jurnal Pendidikan Teknik Elektro, 2(2).

Santiana, N. L. P. M., Sudana, D. N., Garminah, N. N., \& Hum, M. 2014. Pengaruh Model Pembelajaran Kooperatif Tipe Numbered Heads Together (NHT) Terhadap Hasil Belajar Matematika Siswa Kelas V Sekolah Dasar di Desa Alasangker. MIMBAR PGSD Undiksha, 2(1).

Setyo, A. A. 2018. Keefektifan Pembelajaran Kooperatif Tipe Stad Integrasi Teori Belajar Van Hiele Pada Materi Geometri Di Kelas V Sekolah Dasar. Qalam: Jurnal Ilmu Kependidikan, 6(1), 1-11.

Trianto, M. P. 2010. Model Pembelajaran Terpadu. Jakarta: Bumi Aksara

Trisnawati, N. F. 2019. Meningkatkan Hasil Belajar Matematika Siswa Dengan Menggunakan Model Pembelajaran Kooperatif Tipe Think-Pair-Share (Tps) Pada Siswa Kelas Vb Sd Muhammadiyah I Sorong. Qalam: Jurnal Ilmu Kependidikan, 5(2), 26-32.http://siakad.um-sorong.ac.id 